\title{
Iron Oxalate Humboldtine Crystallization by Fungus Aspergillus niger
}

\author{
Marina S. Zelenskaya ${ }^{1, * \mathbb{D}}$, Alina R. Izatulina ${ }^{2} \mathbb{D}$, Olga V. Frank-Kamenetskaya ${ }^{2,3}$ and Dmitry Y. Vlasov ${ }^{1,3}$ \\ 1 Department of Biology, St. Petersburg State University, University Emb. 7/9, 199034 St. Petersburg, Russia; \\ d.vlasov@spbu.ru \\ 2 Crystallography Department, Institute of Earth Sciences, St. Petersburg State University, University Emb. 7/9, \\ 199034 St. Petersburg, Russia; alina.izatulina@spbu.ru (A.R.I.); o.frank-kamenetskaia@spbu.ru (O.V.F.-K.) \\ 3 Inorganic Synthesis Laboratory, Institute of Silicate Chemistry of Russian Academy of Sciences, \\ Adm. Makarova Emb., 2, 199034 St. Petersburg, Russia \\ * Correspondence: m.zelenskaya@spbu.ru
}

Citation: Zelenskaya, M.S.; Izatulina

A.R.; Frank-Kamenetskaya, O.V.;

Vlasov, D.Y. Iron Oxalate

Humboldtine Crystallization by Fungus Aspergillus niger. Crystals 2021, 11, 1591. https://doi.org/ $10.3390 /$ cryst11121591

Academic Editors: Elena Sturm and Carlos Rodriguez-Navarro

Received: 17 November 2021

Accepted: 16 December 2021

Published: 20 December 2021

Publisher's Note: MDPI stays neutral with regard to jurisdictional claims in published maps and institutional affiliations.

Copyright: (c) 2021 by the authors. Licensee MDPI, Basel, Switzerland. This article is an open access article distributed under the terms and conditions of the Creative Commons Attribution (CC BY) license (https:// creativecommons.org/licenses/by/ $4.0 /)$.

\begin{abstract}
Microfungi were able to alternate solid substrate in various environments and play a noticeable role in the formation of insoluble calcium oxalate crystals in subaerial biofilms on rock surfaces. The present work describes how iron oxalate dihydrate humboldtine is acquired under the influence of the acid-producing microscopic fungus Aspergillus niger on the surface of two iron- bearing mineral substrates in vitro. Pyrrhotite and siderite rocks, as well as the products of their alteration, were investigated using a complex of analytical methods, including powder X-ray diffraction, optical microscopy, scanning electron microscopy and EDX spectroscopy. The effect of the underlying rocks with different composition and solubility and different oxidation states of iron on Fe-oxalate crystallization and on the morphology of humboldtine crystals was shown. The mechanisms of humboldtine formation were discussed. The results obtained in vitro seem promising for using fungi in bioleaching iron and other metals from processed ores and for the development of environmentally friendly biotechnologies.
\end{abstract}

Keywords: microbial biomineralization; Aspergillus niger; humboldtine; siderite; pyrrhotite

\section{Introduction}

Microscopic fungi play a significant role in the biological colonization of rocks, causing their biochemical alteration. The formation of insoluble biogenic oxalates on the surface of rocks is often observed under the action of acid-producing fungi [1-3]. It is important to understand the mechanisms of the interaction between lithobiotic microorganisms and rocks, which lead to biomineralization processes [4,5]. Fungi involved in these processes can be utilized for biotechnologies [6].

Iron is a technologically important metal. It is a widespread chemical element and exists in the Earth crust in bivalent and trivalent states in the form of various compounds (oxides, carbonates, salts etc.).

Iron oxalates have a number of valuable properties. In particular, they are characterized by a high thermally activated proton conductivity [7]. They are used in biotechnologies with micromycetes to enrich ores and to clean environmental objects from metal pollution [8]. In addition, due to the ability to remove lead, iron oxalates are used to create new promising lead-free materials [9].

Natural iron oxalate dihydrate humboldtine $\mathrm{Fe}\left(\mathrm{C}_{2} \mathrm{O}_{4}\right) \cdot 2 \mathrm{H}_{2} \mathrm{O}$ is one of the oldest known oxalate minerals. It was discovered in 1821 in Kolowserux, Bohemia, by de Rivero. Its mineralogical research was carried out only in the 20th century [10]. Then, humboldtine was found in brown coal at the D'Arco cape [11] and in association with iron oxides/hydroxides (hematite, magnetite and goethite) at the Cape Calamita mine, Elba Island, Italy [12]; in Minas Gerais, Brazil [13]; and on rock outcrops of Mount Cervandone (Devero Valley, Western-Central Alps, Italy), the latter with other oxalates: whewellite, deveroite, lindbergite and moolooite [14,15]. 
Humboldtine is also often found on rocks containing iron from museum mineralogical collections after cleaning them with oxalic acid [16] and on iron archaeological objects after their restoration using oxalic acid [17].

Humboldtine is of great interest for the scientific community for its formation mechanism. The sources of oxalic acid necessary for oxalate crystallization have not been discussed in most works dedicated to natural humboldtine. However, in a number of works, it was assumed that the products of microorganism metabolism can serve as a source of oxalic acid for the formation of iron oxalate.

It can be assumed that humboldtine in brown coals may be associated with microorganisms since species of bacteria and fungi are found in brown coals [18,19] and are capable of producing oxalic acid. Aramendia et al. [20] suggested that microorganisms can serve as a source of oxalic acid to form iron oxalate humboldtine, which was found on the surface of a steel sculpture displaying corrosion traces in the contact zone with a wooden pallet. Substances of biological nature (carotenoids) were found in samples of the destroyed surface of the steel, containing iron oxalate. However, the microorganisms were not observed. Guastoni et al. $[14,15]$ suggested that the formation of iron and calcium oxalates on rock outcrops of Mount Cervandone in the Alps may be associated with lichen Lecidea geographica, which grows on rocks near the site of oxalate minerals. Humboldtine was not found in the thallus of this lichen.

Ascaso et al. [21] reported about Fe (III) dehydrate oxalate found at the boundary between dolomite rock and the lichen species Caloplaca callopisma and Diploschistes ocellatus. However, this result is questioned by other researchers [22,23]. Moreover, Vlasov et al. [24] showed that the XRD data presented in that paper do not correspond to any of the known ferrous and ferric oxalates, including Fe (III) oxalate dehydrate (according to the ICDD PDF-2 database (release 2016)).

In addition to this, there is an opinion that it is impossible to find humboldtine in biofilms, since a microbial oxidation of Fe (II) to Fe (III) occurs in biofilms, followed by hydrolysis and precipitation of iron (III) oxides or oxo-hydroxides [22,25]. Moreover, it is probable that iron (III) oxalate primarily forms soluble oxalate complexes [26]. The reliability of this assumption is due to the fact that humboldtine has not yet been found in biofilms with lichens and has not been obtained in model experiments under the influence of fungi $[6,24]$.

The objectives of this work were to test the possibility of obtaining iron oxalates under the action of an acid-producing fungus under experimental conditions and, if successful, to analyze the effect of the underlying stone substrate on oxalate formation.

\section{Materials and Methods}

\subsection{Model Experiments}

The fungus Aspergillus niger (strain Ch 4/07), which was used in our previous studies [27-30], was chosen for the experiment as an active producer of oxalic acid [31,32]. The micromycete was obtained from the weathering Proconesos marble column in "Basilica in Basilica" (Tauric Chersonesos, Crimea). A molecular genetic analysis of the fungus strain was performed in the Research Center for "Genomic technologies and cellular biology" of the All-Russian Research Institute of Agricultural Microbiology. The taxonomic affiliation of the strain was based on the sequence of the ITS region of rDNA (GenBank accession no KF768341). Since the strain Ch 4/07 of A. niger is isolated from a natural stone substrate, it is not considered dangerous to humans. Fungus $A$. niger has been previously used by other researchers in model experiments, as well as in biotechnology $[6,8]$.

Two types of fragments of iron ore were used as bedrocks: siderite rock (Dalnegorsk field, Primorsky Territory, Far East, Russia, provided by Yu. M. Bronzova) and pyrrhotite rock (Pyrrhotite Gorge deposit, Khibiny mountains, Kola Peninsula, Russia, obtained by the authors of this paper during the 2018 field season). The selected rocks differ in solubility and in oxidation state of iron ions. Siderite compared to pyrrhotite is less dense and more 
soluble in organic acids secreted by fungi. It contains only $\mathrm{Fe}^{2+}$ ions, while the altered pyrrhotite rock contains iron with a valence higher than two.

The synthesis of iron oxalate under the action of $A$. niger was carried out in liquid Czapek-Dox nutrient medium $\left(\mathrm{NaNO}_{3}-3.0 \mathrm{~g} / \mathrm{L} ; \mathrm{KH}_{2} \mathrm{PO}_{4}-1.0 \mathrm{~g} / \mathrm{L} ; \mathrm{MgSO}_{4} \cdot 7 \mathrm{H}_{2} \mathrm{O}-\right.$ $0.5 \mathrm{~g} / \mathrm{L} ; \mathrm{KCl}-0.5 \mathrm{~g} / \mathrm{L} ; \mathrm{FeSO}_{4} \cdot 7 \mathrm{H}_{2} \mathrm{O}-0.015 \mathrm{~g} / \mathrm{L} ;$ glucose$\left.-30.0 \mathrm{~g} / \mathrm{L}\right)$ at room temperature. The initial $\mathrm{pH}$ of the medium was 5.5. The $\mathrm{pH}$ value of the cultural liquid was constantly controlled. Rock fragments $(\sim 1 \times 0.5 \times 0.5 \mathrm{~cm})$ were placed in Petri dishes, and $15 \mathrm{~mL}$ of nutrient liquid medium was added. Then, $A$. niger conidia and mycelium fragments from a 10-day-old fungal culture obtained on Czapek-Dox agar were added to medium in Petri dishes. The experiments with A. niger and the control experiments (without fungus) ranged from 3 to 18 days. The surfaces of iron bearing bedrocks, precipitates and fungal mycelium were studied on 3, 5, 7, 10, 14 and 18 days. All syntheses were made in triplicate. The nutrient medium and the rock fragments were pre-sterilized by autoclaving.

\subsection{Methods}

Iron bedrocks and the products of biomineralization were investigated by $\mathrm{X}$-ray diffraction, optical and scanning electron microscopy and energy-dispersive $\mathrm{X}$-ray spectroscopy methods.

\subsubsection{Optical Microscopy}

The development of the fungus and the formation of various crystals during the experiment were observed using Leica optical stereo microscopes with digital photo attachments.

\subsubsection{Powder X-ray Diffraction (PXRD)}

The determination of phase composition of the bedrocks and the products of biomineralization was carried out using the PXRD method. Powder X-ray diffractometer Bruker «D2 Phaser» (Bruker AXS, Madison, WI, USA) operated with $\mathrm{CoK} \alpha$ radiation was used. $X$-ray diffraction patterns were received at room temperature in the $2 \theta$ range of $5-70^{\circ}$ with a step of $0.02^{\circ}$ and a counting time of half a second per step. A sample holder from a single crystal silica slice was used to eliminate the background noise. Phase determination was made using the ICDD PDF-2 database (release 2016).

\subsubsection{Scanning Electron Microscopy (SEM) and Energy-Dispersive X-ray (EDX) Spectroscopy}

Morphological studies of the formed crystals and their intergrowths, as well as the elemental composition of bedrocks and crystalline products, were carried out using SEM and EDX analysis. Preliminary diagnostics of biomineralization products were carried out in this way, when it was impossible to use PRXD (with a small amount of substance at the initial stages of the experiments). The investigation was carried out using the TM 3000 (HITACHI, Japan) microscope. For semiquantitative EDX analysis, the microscope was equipped with the Oxford Inca system (Oxford Instruments, Oxford, UK) which operated in a low vacuum $(60 \mathrm{~Pa})$ mode and at an acceleration voltage of $15 \mathrm{kV}$. To avoid the charging effect on SEM images, the samples were coated with a thin carbon layer (High Vacuum Carbon Sprayer Q150TE). The EDX spectra were analyzed by means of the EDAX Genesis software package. The quantitative elemental composition of iron bedrocks was determined on the epoxy mounted, polished and carbon-coated samples by means of the Hitachi S-3400N scanning electron microscope equipped with an AzTec Energy 350 EDX spectrometer, using the following standards: pure iron $(\mathrm{Fe})$, pure manganese $(\mathrm{Mn})$, forsterite and $\mathrm{MgO}(\mathrm{Mg})$, anorthite $(\mathrm{Ca})$, albite $(\mathrm{Na})$, orthoclase $(\mathrm{K})$, celestine $(\mathrm{Sr})$ and barite (Ba). EDX spectra were obtained under a $25 \mathrm{kV}$ accelerating voltage and $10 \mathrm{nA}$ beam current. Siderite formula was calculated assuming Fe $+\mathrm{Mn}+\mathrm{Mg}$ content equal to 1; pyrrhotite formula was calculated using the $\mathrm{Fe}$ and $\mathrm{S}$ atomic ratio. 


\section{Results}

\subsection{Mineral and Elemental Composition of Underlying Rocks}

According to the PXRD and EDX results, siderite rock was represented mainly by ferrous carbonate siderite containing impurities of $\mathrm{Mg}^{2+}$ and $\mathrm{Mn}^{2+}$ ions, which corresponds to the formula $\left(\mathrm{Fe}_{0.81-0.88} \mathrm{Mg}_{0.08-0.12} \mathrm{Mn}_{0.04-0.07}\right) \mathrm{CO}$. The impurity phases were pyrite, muscovite, quartz and montmorillonite. In pyrrhotite rock ore, mineral pyrrhotite $\mathrm{Fe}_{1.04-1.22} \mathrm{~S}_{1.66-2.02}$ was largely replaced by poorly crystallized iron oxides and hydroxides. Quartz, kaolinite and albite were present as impurity phases. Biotite was also found in some areas.

\subsection{Humboldtine Formation In Vitro under the Action of the Fungus Aspergillus niger}

On siderite rock. On SEM images of the siderite surface on the third day of the experiment, the beginning of the dissolution of the underlying rock and a few lamellar crystals enriched in calcium were observed. This allowed us to identify them as crystals of calcium oxalate monohydrate whewellite.

The formation of iron oxalate dihydrate humboldtine $\mathrm{Fe}^{2+}\left(\mathrm{C}_{2} \mathrm{O}_{4}\right) \cdot 2 \mathrm{H}_{2} \mathrm{O}$ on the siderite surface was recorded by PXRD (Figure 1a) and EDX (Figure 1c) on the fifth day of the experiment at $\mathrm{pH}=3.5 \pm 0.5$. According to SEM data, humboldtine was represented by numerous monoclinic elongated crystals of prismatic habit, the size of which varied significantly along the elongation axis perpendicular to the two-fold axis (from 10 to $40 \mu \mathrm{m}$ ) (Figure 2a). In addition to well-developed prism faces parallel to the elongation axis, some of the smaller crystals had more poorly developed prism faces with splitting, located at an angle. According to EDX data, humboldtine crystals contained Mg and Mn impurities (Figure 1c), which came from the underlying rock (see Section 3.1).
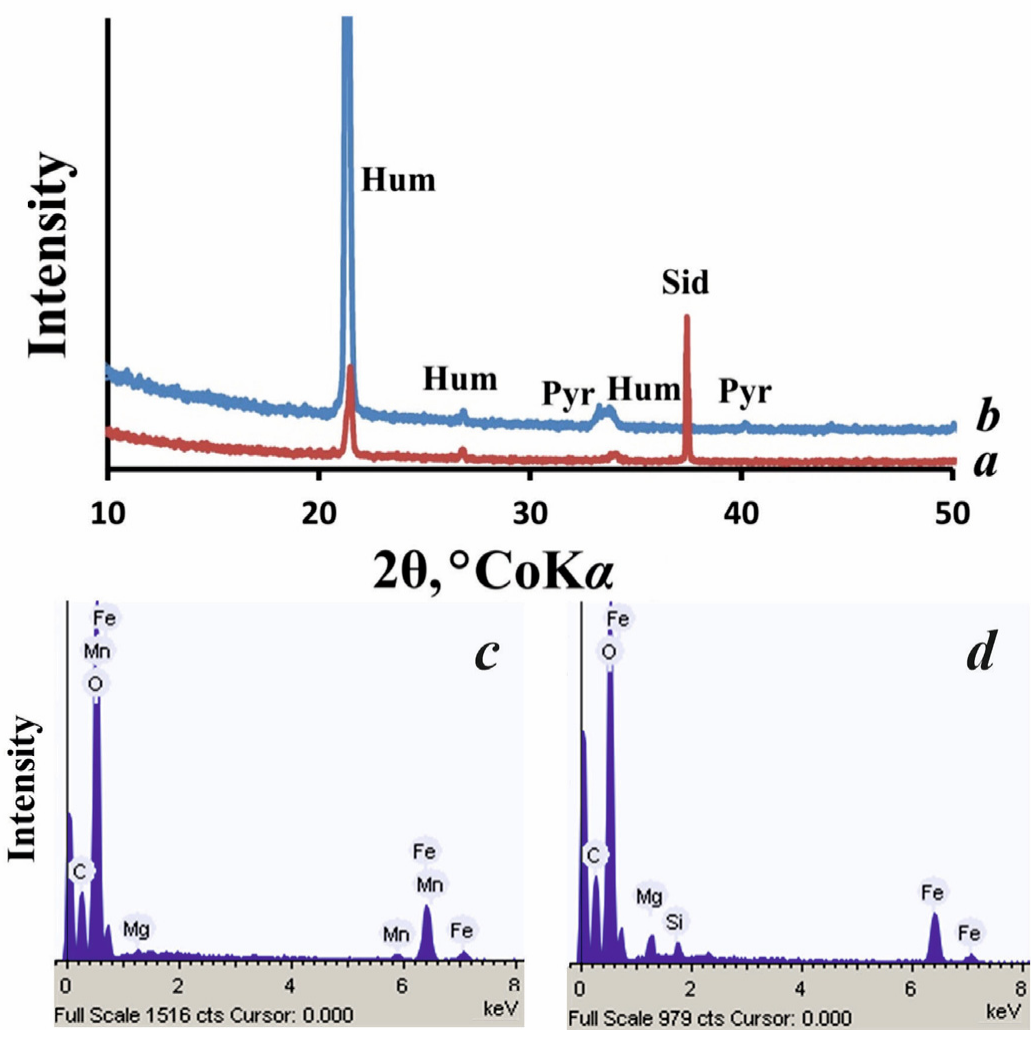

Figure 1. Identification of humboldtine according to PXRD (a,b) and EDX spectra (c,d): (a) - X-ray pattern of humboldtine on siderite (5 days), (b) - X-ray pattern of humboldtine on pyrrhotite (7 days), (c) -EDX spectra of humboldtine on siderite, (d) -EDX spectra of humboldtine on pyrrhotite. Humhumboldtine, Sid-siderite, Pyr-pyrrhotite. 

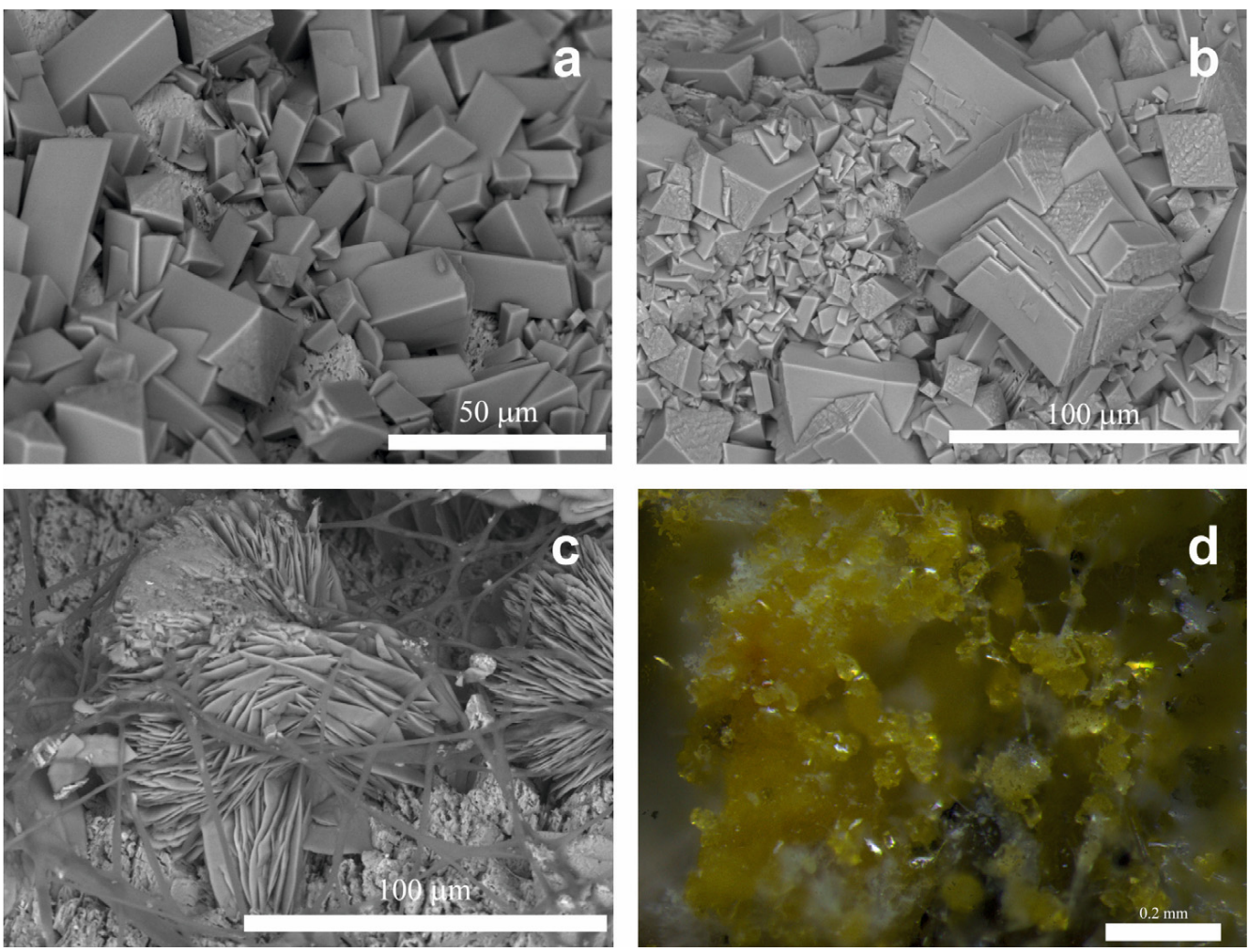

Figure 2. Formation of humboldtine crystals under the action of $A$. niger on the siderite surface: (a) - SEM image on the 5th day, (b) - SEM image on the 7th day, (c) - SEM image on the 18th day, (d) - under a light microscope on the 18th day.

As the exposure increased, the $\mathrm{pH}$ did not change significantly, the dissolution of the underlying rock became more intense, the crystals of humboldtine began to split (Figure $2 b$ ), and their number increased, and on the 18th day, a carpet of spherulite-like intergrowths of crystals was visible on the siderite surface (Figure 2c). At this stage, humboldtine crystals were clearly visible even under a light microscope (Figure 2d).

On pyrrhotite rock. The formation of humboldtine on the surface of pyrrhotite, largely substituted by oxides and hydroxides (see Section 3.1), began earlier than that on the surface of siderite but proceeded more slowly. According to the PXRD (Figure 1b) and EDX data (Figure 1d), humboldtine was observed on the seventh day of the experiment at the same $\mathrm{pH}$ as that on the siderite surface. However, on the SEM images, already on the third day of the experiment, in addition to the beginning of the dissolution of the underlying rock, few crystals of prismatic habit (10-20 $\mu \mathrm{m}$ in size) (Figure 3a) enriched with iron were visible. According to the EDX data, humboldtine crystals contained Mg impurity, which came from the underlying rock (Figure 1d). 

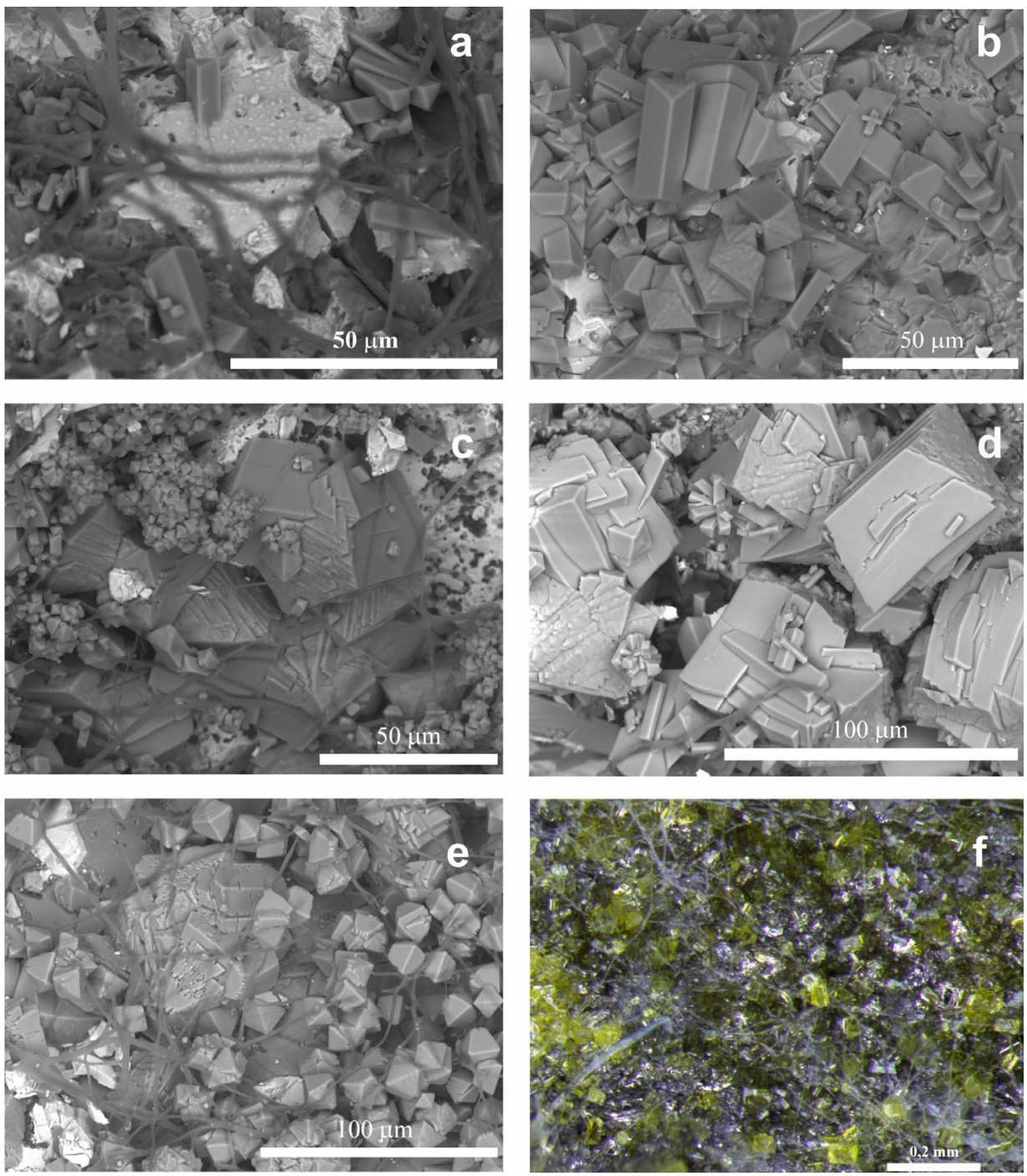

Figure 3. Formation of humboldtine crystals under the action of A. niger on the pyrrhotite surface: (a) - SEM image on the 3rd day, (b) - SEM image on the 7th day, (c) - SEM image on the 10th day, (d) - SEM image on the 14th day, (e) - SEM image on the 18th day, (f) — under a light microscope on the 18 th day.

On the seventh day, the number of humboldtine crystals increased, and the picture became similar to that observed on siderite on the fifth day. A new generation of crystals appeared, the morphology of which was represented by two prisms, differently inclined to the elongation axis (Figure $3 b$ ). The beginning of the splitting of humboldtine crystals was recorded on 10th day (Figure 3c) (on siderite on the 7th day) and increased with exposure (Figure 3d). On the 18th day, the generation of crystals with two prisms, differently oriented with respect to the crystal elongation, became dominant (Figure 3e). The crystals showed clear signs of active dissolution and covered the entire surface of the underlying mineral substrate. At this stage, the crystals of humboldtine were also clearly visible already under the light microscope (Figure 3f). After 7 days, the $\mathrm{pH}$ values in the experiment with pyrrhotite slightly decreased as the humboldtine crystallized and reached a minimum value of 2 on the 14th day. After that, a slight increase in $\mathrm{pH}$ began, and on the 18th day of the experiment, the $\mathrm{pH}$ reached the initial value of $3.5 \pm 0.5$. The control experiment showed that in the absence of the fungus $A$. niger, the formation of iron oxalate crystals did not occur (Figure 4). 

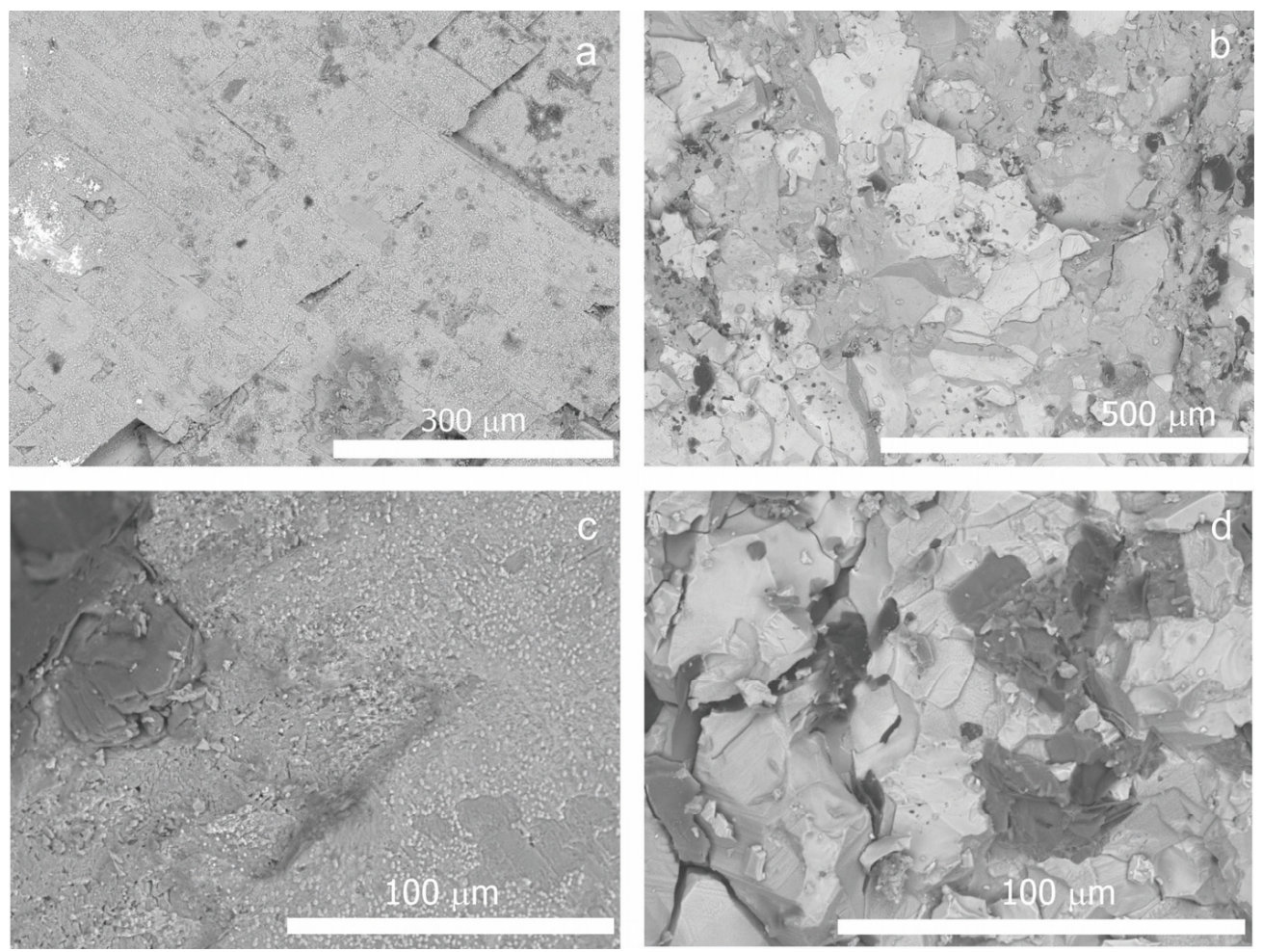

Figure 4. The surface of siderite (a) and pyrrhotite (b) before experiment. The surface of siderite (c) and pyrrhotite (d) in control experiment.

\section{Discussion}

In our experimental study, we obtained iron oxalate dihydrate humboldtine under the action of the acid-producing fungus $A$. niger on the surface of two iron-bearing mineral substrates differing by iron oxidation state and by solubility (pyrrhotite and siderite rocks). During the experiment, both underlying rocks dissolved significantly under the action of the organic acids released by $A$. niger. At the same time, the formation of humboldtine began earlier (on days 3 and 5, respectively) on weathered pyrrhotite rock, in which the ore mineral had been largely replaced by iron oxides and hydroxides, than on siderite. However, the crystallization on pyrrhotite proceeded more slowly than that on siderite rock. The earlier formation of humboldtine on pyrrhotite as compared to siderite indicates that the solubilization and crystallization processes leading to the iron oxalate formation on these substrates differ significantly. At the hypothesis level, by analogy with modeling $\mathrm{Mn}$ oxalates under the action of $A$. niger previously performed by us [33], this can be explained via complex redox processes $\left(\mathrm{Fe}^{2+}\right.$ to $\mathrm{Fe}^{3+}$ and vice versa), which depend on the oxidation state of iron ions in the underlying mineral substrate and on the $\mathrm{pH}$ of the crystallization medium. The slower crystallization of humboldtine on pyrrhotite as compared to siderite indicates a lower solubility of pyrrhotite and iron oxides and hydroxides replacing it in the products of fungus metabolism. It slows down the processes of Fe leaching and Fe-oxalate crystallization that occurs in a more acidic (compared to siderite) medium.

The formation of calcium oxalate monohydrate whewellite on day 3 of the experiment can be explained by the presence of a small amount of montmorillonite in the underlying rock, and possibly inclusions of other Ca-containing minerals (for example, calcite), the determination of which was beyond the capabilities of PRXD. The fact that calcium oxalate appeared on siderite before humboldtine indicates that $\mathrm{Ca}^{2+}$ ions were leached from the underlying substrate under the action of aggressive metabolites of $A$. niger more intensively than iron ions.

The formation of oxalates on siderite and pyrrhotite that started in an acidic medium at the same $\mathrm{pH}$ value $(3.5 \pm 0.5)$ slightly decreased in comparison with the process in the initial medium $\mathrm{pH}$ value of 5.5. On the siderite surface, the $\mathrm{pH}$ did not change significantly, 
as the exposure increased up to 18 days, which may have been due to the presence of carbonate ion in the solution [29]. As humboldtine crystallizes on pyrrhotite, the $\mathrm{pH}$ decreased to 2 (on the 14th day) and then began to grow slowly, reaching the initial value of $3.5 \pm 0.5$ on the 18th day. This may be associated with a decrease in oxalate ion content in the solution due to intense crystallization, as well as with the aging of the fungus culture [27].

The size of the formed crystals along the elongation axis was $10 \mu \mathrm{m}$ at the first stage of the reactions (after $\sim 5$ days on siderite, Figure $2 \mathrm{a}$, and after 3 and 7 days on pyrrhotite, Figure $3 a, b)$. They were elongated crystals with well-developed prism faces parallel to the elongation axis, which were similar to crystals observed in nature on the surface of rock outcrops of Mount Cervandone in the Alps [14]. The natural crystals of humboldtine were characterized by slightly rounded ribs, which is typical of crystals formed in biofilms with a predominance of lichens and is associated with the presence of the intracrystalline solutions in lichens, the influence of which depends on repeated dehydration/rehydration cycles in the lichens, and leads to an intensive dissolution of crystals in biofilms [34,35].

Our results showed that the impurity irons entering the crystallization medium from the underlying rocks significantly affect the morphology of synthesized humboldtine crystals and their intergrowths. Slightly elongated humboldtine crystals containing magnesium (Figure 1c,d) faceted by two prisms, differently oriented with respect to elongation, were similar in morphology to magnesium oxalate dihydrate glushinskite-a mineral that belongs to the humboldtine group and is isotopical with it. Such crystals were visible on the siderite, as well as on the pyrrhotite surface (Figures 2a and 3). On the 18th day, they fully covered the pyrrhotite surface (Figure 3e). Spherulite-like intergrowths of humboldtine crystals on siderite (Figure 2c) were typical for Mn oxalate dihydrate lindbergite, synthesized by us under the action of $A$. niger [33], and are isostructural to humboldtine.

The metabolism of microorganism associations differs significantly from the metabolism of individual species, does not obey the rule of additivity and significantly affects the processes of oxalate formation in biofilms $[29,36]$. Therefore, the results of the performed model experiment with $A$. niger do not allow for an unambiguous answer as to whether humboldtine can form in biofilms containing fungi and lichens on iron-bearing rocks. We conducted a detailed search for iron oxalates in biofilms with a predominance of lichens from the iron ores of the Kola Peninsula (Pyrrhotite Gorge deposit, Khibiny) and Karelia (Koikarskoye iron ore deposit, left bank of the Suna river). Iron oxalates have never been found. However, using PXRD and SEM, we found an incrustation of hyphae of the mycobiont in the cortex, and microgranules of iron hydroxide of goethite were found (Figure 5) in the lichen thallus Acarospora sinopica on the surface of pyrrhotite rock. Goethite was also found in the Bellemerea alpina and Lecidea lapicida lichens in the same deposit. Earlier, a layer of iron oxide microgranules in the cortex of lichens of the genus Acarospora had been discovered by Purvis et al. [37]. The formation of ferric oxide on lichen hyphae is probably related to the ease of oxidation of iron in air. The behavior of the Fe (II)/Fe (III) oxalate system is extremely complex, as shown by various experimental studies [38]. Microbial oxidation or oxidation of Fe (II) to Fe (III) occurs in air, followed by hydrolysis and precipitation of iron oxides [22]. In addition, iron (III) is likely to primarily form soluble oxalate complexes [26]. Purvis et al. suggested that the formation of oxides in the cortical layer of lichens can have a protective role in high mountains as a response to stress and as a protection of a lichen phycobiont from excessive insolation [37]. 

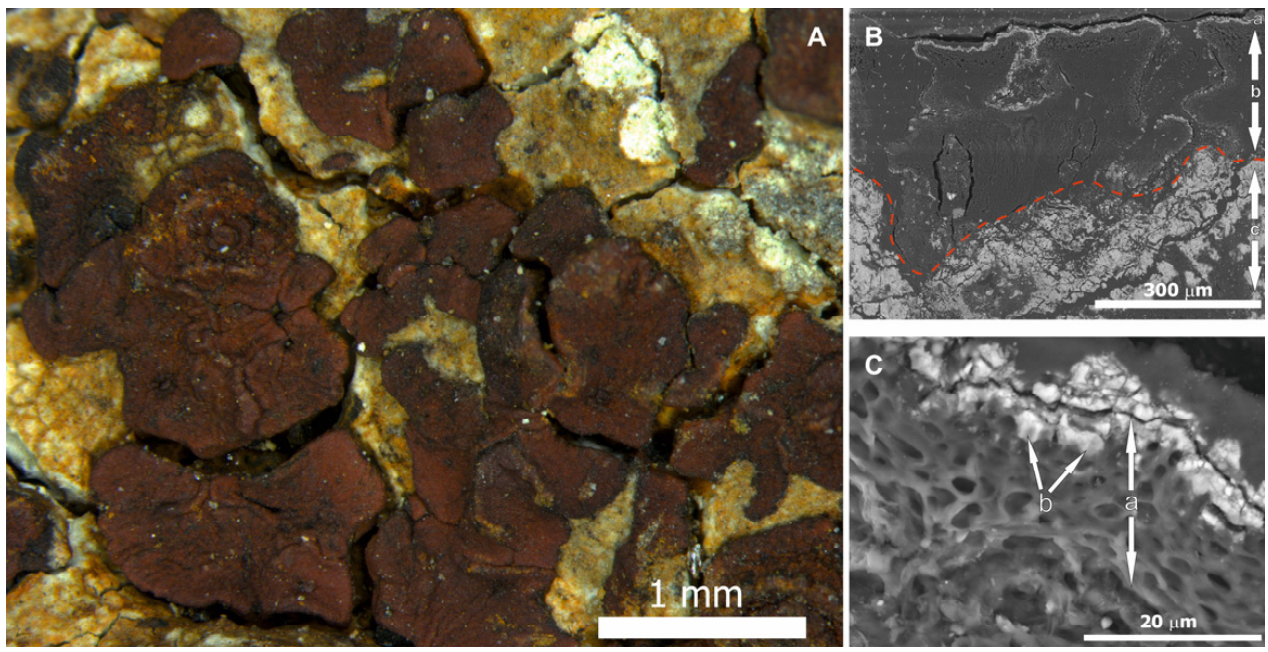

Figure 5. Incrustation of mycobiont hyphae with microgranules of iron hydroxide in the cortex of the lichen Acarospora sinopica on the surface of pyrrhotite rock (Pyrrhotite Gorge deposit, Khibiny mountains, Kola Peninsula): (A)—squamules of Acarospora sinopica lichen thallus; (B)—section through pyrrhotite bedrock (c) and lichen thallus Acarospora sinopica (b); (C)—lichen cortex (a) with microgranules of iron hydroxide of goethite (b).

\section{Conclusions}

Iron oxalate humboldtine was obtained in vitro under the action of fungus $A$. niger. The influence of the iron oxidation state, impurity composition and solubility of the underlying iron-containing rocks on crystallization and on the morphology of humboldtine crystals was studied. The mechanisms of iron oxalate formation were discussed.

The present work contributes to the studies of biomineralization mechanisms under the influence of lithobiotic microbial community (in particular, microscopic fungi). The obtained results demonstrate a significant effect of the chemical composition of the underlying mineral substrate on the processes of mineralization under the action of microorganisms. The observed patterns are important for understanding the processes occurring when using micromycetes, in particular, A. niger, in the bioleaching of iron and other metals from processed ores, as well as for cleaning environmental objects of heavy metals.

Author Contributions: Conceptualization, M.S.Z., A.R.I., D.Y.V. and O.V.F.-K.; methodology, M.S.Z., A.R.I., D.Y.V. and O.V.F.-K.; investigation, M.S.Z. and A.R.I.; writing-original draft preparation, M.S.Z. and A.R.I.; writing-review and editing, M.S.Z., A.R.I., D.Y.V. and O.V.F.-K.; visualization, M.S.Z. and A.R.I. All authors have read and agreed to the published version of the manuscript.

Funding: This research was funded by the Russian Science Foundation (grant 19-17-00141).

Institutional Review Board Statement: Not applicable.

Informed Consent Statement: Not applicable.

Acknowledgments: The authors would like to thank Gimelbrant D.E. and Stepanchikova I.S. for consultations provided during the preparation of the article. The laboratory research was carried out in the Research Park of Saint Petersburg State University; the SEM investigations were carried out in the "Resource Center Microscopy and Microanalysis (RCMM)" and in the Centre for GeoEnvironmental Research and Modelling (Geomodel); the XRD measurements were carried out in the X-ray Diffraction Centre. We are grateful to reviewers for their useful comments.

Conflicts of Interest: The authors declare no conflict of interest. 


\section{References}

1. Gadd, M.G. Mycotransformation of organic and inorganic substrates. Mycologist 2004, 18, 60-70. [CrossRef]

2. Gadd, M.G. Geomycology: Biochemical transformation of rocks, minerals, metals and radionuclides by fungi, bioweathering and bioremediation. Mycol. Res. 2007, 111, 3-49. [CrossRef] [PubMed]

3. Gorbushina, A.A. Life on the rocks. Environ. Microbiol. 2007, 9, 1613-1631. [CrossRef] [PubMed]

4. Gadd, M.G. Fungi, rocks and minerals. Elements 2017, 13, 171-176. [CrossRef]

5. Burford, E.P.; Kierans, M.; Gadd, J.M. Geomycology: Fingi in mineral substrata. Mycologist 2003, 17, 98-107. [CrossRef]

6. Gadd, G.M.; Bahri-Esfahani, J.; Li, Q.; Rhee, Y.J.; Wei, Z.; Fomina, M.; Liang, X. Oxalate production by fungi: Significance in geomycology, biodeterioration and bioremediation. Fungal Biol. Rev. 2014, 28, 36-55. [CrossRef]

7. Yamada, T.; Sadakiyo, M.; Kitagawa, H. High proton conductivity of one-dimensional ferrous oxalate dihydrate. J. Am. Chem. Soc. 2009, 131, 3144-3145. [CrossRef] [PubMed]

8. Ren, W.-X.; Li, P.-J.; Geng, Y.; Li, X.-J. Biological leaching of heavy metals from a contaminated soil by Aspergillus niger. J. Hazard. Mater. 2009, 167, 164-169. [CrossRef] [PubMed]

9. Müller, H.; Bourcet, L.; Hanfland, M. Iron(II) oxalate Dihydrate-Humboldtine: Synthesis, Spectroscopic and Structural Propertiesof a Versatile Precursor for High Pressure Research. Minerals 2021, 11, 113. [CrossRef]

10. Baran, E.J. Natural iron oxalates and their analogous synthetic counterparts: A review. Chem. Erde 2016, 76, 449-460. [CrossRef]

11. Manasse, E. Oxalite di Capo d'Arco (Isola di Elba). Rendicon. Accad. Naz. Lincei 1910, 19, 138-146.

12. Garavelli, C.L. Ritrovamento de oxalite tra i minerali secondari delgiacimento de Capo Calamita. Rend. Soc. Mineral. Ital. 1955, 11, 176-181.

13. Matioli, P.A.; Atencio, D.M.; Coutinho, J.M.V.; Menezes Filho, L.A.D. Humboldtina de Santa Maria de Itabira Minas Gerais, primeira ocorrênciabrasileira e primeira ocorrência mundial em fraturas de pegmatito. An. Acad. Bras. Ciências 1997, 69, 431-432.

14. Guastoni, A.; Nestola, F.; Gentile, P.; Zorzi, F.; Alvaro, M.; Lanza, A.; Peruzzo, L.; Schiazza, M.; Casati, N.M. Deveroite-(Ce): A new REE-oxalate from Mount Cervandone, Devero Valley, Western-Central Alps, Italy. Mineral. Mag. 2013, 77, $3019-3026$. [CrossRef]

15. Guastoni, A.; Gentile, P.; Nestola, F.; Soldani, V.; Zorzi, F. Humboldtina e whewellite due nuoviossalati per il Monte Cervandone, valle Devero (VB). Riv. Mineral. Ital. 2015, 4, 250-254.

16. Green, D.I. Anthropogenic humboldtine from Cornwall, England. Geol. Curator 2004, 8, 33-36.

17. Alonso, E.G. Lapresencia de humboldtina comoconsecuencia de un tratamiento de restauraciyn de hierroarqueolygico. Inf. $Y$ Trab. 2014, 10, 187-194.

18. Bulankina, M.A.; Lysak, L.V.; Zvyagintsev, D.G. Lignite Microorganisms. Biol. Bull. 2007, 34, 194-197. [CrossRef]

19. Sezen, S.; Gulluce, M.; Karadayi, M.; Alaylar, B. First report of fungal strains from Afs, in-Elbistan Mine for microbial lignite process. Geomicrobiol. J. 2020, 37, 143-146. [CrossRef]

20. Aramendia, J.; Gomez-Nubla, L.; Bellot-Gurlet, L.; Castro, K.; Arana, G.; Madariaga, J.M. Bioimpact on weathering steel surfaces: Oxalates formation and the elucidation of their origin. Int. Biodeterior. Biodegrad. 2015, 104, 59-66. [CrossRef]

21. Ascaso, C.; Galvan, J.; Rodgriguez-Pascual, C. The weathering of calcareous rocks by lichens. Pedobiologia 1982, 24, $219-229$.

22. Adamo, P.; Violante, P. Weathering of rocks and neogenesis of mineralsassociated with lichen activity. Appl. Clay Sci. 2000, 16, 229-256. [CrossRef]

23. Chen, J.; Blume, H.P.; Beyer, L. Weathering of rocks induced by lichencolonization. A review. Catena 2000, 39, 121-146. [CrossRef]

24. Vlasov, D.Y.; Frank-Kamenetskaya, O.V.; Zelenskaya, M.S.; Sazanova, K.V.; Rusakov, A.V.; Izatulina, A.R. The use of Aspergillus niger in modeling of modern mineral formation in lithobiotic systems. In Aspergillus Niger: Pathogenicity, Cultivation and Uses; Nova Science Publishers: New York, NY, USA, 2020; pp. 1-123.

25. Monje, P.V.; Baran, E.J. Plant biomineralization. In Advances in Plant Physiology; Hemantaranjan, A., Ed.; Scientific Publishers: Jodhpur, India, 2004; Volume 7, pp. 395-410.

26. Baran, E.J.; Monje, P.V. Biomineralization. From Nature to Application. In Metal Ions in Life Sciences; Sigel, A., Sigel, H., Sigel, R.K.O., Eds.; Wiley: New York, NY, USA, 2008; Volume 4, pp. 219-254.

27. Sturm, E.V.; Frank-Kamenetskaya, O.V.; Vlasov, D.Y.; Zelenskaya, M.S.; Sazanova, K.V.; Rusakov, A.V.; Kniep, R. Crystallization of calcium oxalate hydrates by interaction of calcite marble with fungus Aspergillus niger. Am. Mineral. 2015, 100, $2559-2565$. [CrossRef]

28. Rusakov, A.V.; Vlasov, A.D.; Zelenskaya, M.S.; Frank-Kamenetskaya, O.V.; Vlasov, D.Y. The crystallization of calcium oxalate hydrates formed by interaction between microorganisms and minerals. In Biogenic-Abiogenic Interactions in Natural and Anthropogenic Systems. Lecture Notes in Earth System Sciences; Frank-Kamenetskaya, O., Panova, E., Vlasov, D., Eds.; Springer: Cham, Switzerland, 2016; pp. 357-377.

29. Frank-Kamenetskaya, O.V.; Ivanyuk, G.Y.; Zelenskaya, M.S.; Izatulina, A.R.; Kalashnikov, A.O.; Vlasov, D.Y.; Polyanskaya, E.I. Calcium oxalates in lichens on surface of apatite-nepheline ore (Kola Peninsula, Russia). Minerals 2019, 9, 656. [CrossRef]

30. Zelenskaya, M.S.; Rusakov, A.V.; Frank-Kamenetskaya, O.V.; Vlasov, D.Y.; Izatulina, A.R.; Kuz'mina, M.A. Crystallization of calcium oxalate hydrates by interaction of apatites and fossilized tooth tissue with fungus Aspergillus niger. In Processes and Phenomena on the Boundary between Biogenic and Abiogenic Nature; Frank-Kamenetskaya, O.V., Panova, E.G., Vlasov, D.Y., Lessovaia, S., Eds.; Springer: Cham, Switzerland, 2020; pp. 581-603. 
31. Barinova, K.V.; Vlasov, D.Y.; Schiparev, S.M.; Zelenskaya, M.S.; Rusakov, A.V.; Frank-Kamenetskaya, O.V. Production of organic acids by micromycetes from the rock substrates. Mycol. Phythopathol. 2010, 44, 137-142. (In Russian)

32. Sazanova, K.; Osmolovskaya, N.; Schiparev, S.; Yakkonen, K.; Kuchaeva, L.; Vlasov, D. Organic acids induce tolerance to zincand copper-exposed fungi under various growth conditions. Microbiology 2014, 83, 1-9. [CrossRef] [PubMed]

33. Frank-Kamenetskaya, O.; Zelenskaya, M.; Izatulina, A.; Gurzhiy, V.; Rusakova, A.; Vlasov, D. Oxalate formation by Aspergillus niger on manganese ore minerals. Am. Mineral. 2022; in press. [CrossRef]

34. Honegger, R. Water relations in lichens. In Fungi in the Environment; Gadd, G.M., Watkinson, S.C., Dyer, P., Eds.; Cambridge University Press: New York, NY, USA, 2006; pp. 185-200.

35. Rundel, P.W. Water relations. In CRC Handbook of Lichenology; Galun, M., Ed.; CRC Press: Boca Raton, FL, USA, 1988; Volume 2, pp. 17-36.

36. Sazanova, K.V.; Frank-Kamenetskaya, O.V.; Vlasov, D.Y.; Zelenskaya, M.S.; Vlasov, A.D.; Rusakov, A.V.; Petrova, M.A. Carbonate and oxalate crystallization by interaction of calcite marble with Bacillus subtilis and Bacillus subtilis-Aspergillus niger association. Crystals 2020, 10, 756. [CrossRef]

37. Purvis, O.W.; Kearsley, A.; Cressey, G.; Crewe, A.T.; Wedin, M. Mineralization in rust-coloured Acarospora. Geomicrobiol. J. 2008, 25, 142-148. [CrossRef]

38. Molinier, M.; Price, D.J.; Wood, P.T.; Powell, A.K. Biomimetic control of ironoxide and hydroxide phases in the iron oxalate system. J. Chem. Soc. Dalton Transact. 1997, 21, 4061-4068. [CrossRef] 